\title{
Blossom Thinners Reduce Crop Load and Increase Fruit Size and Quality of Peaches
}

\author{
Elina D. Coneva ${ }^{1}$ and John A. Cline \\ Department of Plant Agriculture, University of Guelph, 4890 Victoria Ave. N., \\ Vineland Station, Ontario LOR 2E0, Canada
}

Additional index words. peach, thinning, crop load, fruit quality, fruit size

\begin{abstract}
The purpose of this research was to determine the effectiveness of three blossom-thinning compounds on crop density and fruit quality of two peach cultivars. Treatments consisted of $15 \mathrm{ml} \cdot \mathrm{L}^{-1}$ and $30 \mathrm{ml} \cdot \mathrm{L}^{-1}$ ammonium thiosulphate, $30 \mathrm{ml} \cdot \mathrm{L}^{-1}$ and $40 \mathrm{ml} \cdot \mathrm{L}^{-1}$ decyl alcohol, and $40 \mathrm{ml} \cdot \mathrm{L}^{-1}$ lime sulfur. Treatments were applied to 'Redhaven' and 'Harrow Diamond' peach trees at two phenological stages: $80 \%$, and $100 \%$ full bloom in 2002 and 2003. In both years, treatments reduced the crop density in both cultivars, and in 2003 the amount of hand thinning required to adjust the crop load was significantly reduced. Fruit size from several blossom-thinned treatments was comparable with that observed from hand-thinned trees. However, treatments caused significant leaf phytotoxicity to 'Harrow Diamond' trees in 2003, likely a result of hand spray gun applications. These data indicate that chemical sprays at bloom can be used successfully to reduce fruit set, but are very environmentally, dose, and cultivar dependent.
\end{abstract}

Stone fruit trees commonly produce an excessive number of flowers, and thinning is required to set an acceptable yield of large fruit and to maximize returns. Therefore, thinning practices, conducted preferably during the growing season, are necessary to optimize fruit size and quality, and to balance tree growth and cropping (Byers, 1989; Byers and Lyons, 1984a, b; Havis, 1962; Webster and Andrews, 1986). The primary impetus of chemical thinning is to reduce the labor cost of hand thinning, currently established at $\$ 1057 /$ ha in Ontario (Slingerland and Molenhuis, 2003). Also, bloom thinners that reduce set early offer the advantage of diverting photosynthates to fewer sinks and, subsequently, increase fruit size.

In the 1980 s, surfactants, fertilizers, desiccants, long-chain fatty acids, and oils were investigated for potential flower-thinning compounds for peaches (Byers et al., 2003). Several chemicals were found to interfere with peach pollination and fertilization. Ammonium thiosulphate (ATS) was among the most effective flower thinners for peach (Byers and Lyons, 1984a; 1985; Greene et al., 2001). The most effective timing for ATS was when $70 \%$ to $90 \%$ of the flowers had opened (Byers, 1999). Furthermore, because ATS is an agricultural fertilizer, its use as a thinning compound may be easier to justify commercially (Balkoven-Baart and

\footnotetext{
Received for publication 17 Mar. 2006. Accepted for publication 27 Apr. 2006. Financial assistance for this research was provided in part by the Natural Sciences and Engineering Research Council, the University of Guelph, and the Niagara Peninsula Fruit and Vegetable Growers Association.

${ }^{1}$ To whom reprint requests should be addressed; e-mail econeva@uoguelph.ca
}

som thinning response in apple and peach (Westwood, 1993). The performance of the blossom thinners are therefore likely to vary by growing region and by cultivar (Fallahi, 1997).

Even though blossom thinning peaches with various chemical products has been extensively studied for the past two decades, information is lacking on the effects of chemical thinners on peaches in Ontario, and more specifically in the region of the Niagara peninsula, where $75 \%$ of the Canadian peach-growing industry is concentrated.

The primary objective of this study was to investigate the effectiveness of the blossomthinning compounds ATS, decyl alcohol, and lime sulfur, applied at various concentrations and timings, on fruit set and quality of 'Redhaven' and 'Harrow Diamond' peach trees. ATS is included in our study as a standard peach blossom thinner to ensure comparable results (Fallahi et al., in press). Lime sulfur was selected because of its widespread use as a blossom thinner for apples, and because it is suitable for organic fruit certification programs. The effect of decyl alcohol as a potential flower-thinning agent for peaches has not been reported in the literature.

\section{Materials and Methods}

Wertheim, 1997). Pelargonic acid and several other long-chain fatty acids have been investigated as potential bloom thinners because they are sufficiently phytotoxic yet short-lived in plant tissues (Byers, 1999; Fallahi, 1997; Klein and Cohen, 1995). Some fatty alcohols, such as decyl alcohol, which is currently registered for the control of tobacco suckers, is a prospective but untested flower thinner. More recent studies have demonstrated that lime sulfur, a product used in organic fruit production (Fallahi et al., 2003; Noordijk and Schupp, 2003; Warner, 2002), is also efficacious in reducing the set of apples and peaches (Fallahi et al., 2003; Meland, 1997; Noordijk and Schupp, 2003).

Another approach for regulating the crop load of stone fruits is to inhibit flower induction and initiation. This has been successful with foliar applications of gibberellic acid $\left(\mathrm{GA}_{3}\right)$ during the stage of flower bud initiation the season before flowering (Byers et al., 1990; Southwick and Fritts, 1995; Southwick et al., 1995; Unrath, 1974; Coneva and Cline, unpublished data). $\mathrm{GA}_{3}$, (Ralex; Valent Biosciences Corp., Libertyville, Ill.) is currently registered for stone fruits only in California, Oregon, and Washington (Marini, 2003).

Although chemical bloom thinning may cause overthinning if it coincides with inclement weather during or shortly after bloom, the potential advantages of such a strategy, and the lack of a suitable chemical fruitlet thinning agent for Prunus species warrant further research to develop alternatives to traditional hand thinning (Southwick et al., 1998). The time of application in relation to phenological stage of flower/fruit development, air temperature at and after application, and cultivar sensitivity all appear to be important factors influencing the blos-

\section{'Redhaven' 2002}

An experiment was conducted in 2002 on 9-year-old 'Redhaven' peach trees, grafted on various rootstocks located at the University of Guelph, Vineland Campus, Ontario. Trees were spaced at $5.0 \mathrm{~m}$ within rows and $6.0 \mathrm{~m}$ between rows (333 trees/ha), trained to a freestanding open vase and managed according to standard practices for Ontario (Anonymous, 2004).

Twelve treatments were made to single whole trees in a randomized complete block design with four replications. Experimental units received one of the following treatments: $15 \mathrm{ml} \cdot \mathrm{L}^{-1}$ or $30 \mathrm{ml} \cdot \mathrm{L}^{-1}$ ATS (Oligo-S; Oligosol Ltd., Beloeil, Quebec) plus 0.3\% (volume/volume) Regulaid (Kalo Inc., Overland Park, Kan.) and $0.05 \%$ (volume/volume) antifoam agent; $30 \mathrm{ml} \cdot \mathrm{L}^{-1}$ or $40 \mathrm{ml} \cdot \mathrm{L}^{-1}$ decyl alcohol (Pfizol-10; United Agri Products, Dorchester, Ontario) plus $0.05 \%$ (volume/ volume) antifoam agent; $40 \mathrm{ml} \cdot \mathrm{L}^{-1}$ lime sulfur (United Agri Products) plus 0.3\% (volume/volume) Regulaid. Treatments were applied to each experimental unit at one of the two timings: "early" application at $80 \%$ full bloom or "late" application at $100 \%$ full bloom at a volume of $2300 \mathrm{~L} \cdot \mathrm{ha}^{-1}$. Untreated and hand-thinned control treatments were also included for comparison purposes.

In 2002, the "early" spray treatments were made on May 5, when the experimental trees reached $80 \%$ full bloom stage; the "late" treatments were sprayed on May 8 on a different group of trees, when $100 \%$ full bloom was recorded. A commercial air-blast sprayer (Unigreen SPA Spraying Equipment, Model GB Laser P7, Cavazolli, Italy) was used. To prevent spray drift, at least one guard tree was left between the experimental 
units. Ten fruiting shoots per tree $(30-60 \mathrm{~cm}$ long) selected randomly between 1.0 to $2.0 \mathrm{~m}$ above the ground, were marked at bloom, and the number of flower buds and shoot length recorded to evaluate flower density. Fruitlet counts were made on these shoots to determine the final fruit set after the handthinned controls were thinned to a commercially accepted level of 15 to $20 \mathrm{~cm}$ between fruits on June 20 (43 days after full bloom). No additional hand thinning was conducted, except on the hand-thinned control treatments, because of labor constraints. Strong winds on Aug. 8 caused premature fruit drop; the number and weight of fallen fruit per experimental unit were recorded. Fruits were harvested on Aug. 15 and 26, because 'Redhaven' is a multipick cultivar, based on uniform background color. The yield and total number of fruit harvested per tree in each pick were recorded. The length and number of extension shoots were recorded from two scaffold limbs (10-12-cm circumference) per tree after leaf fall in 2002 to evaluate treatment effects on vegetative growth.

Fruit firmness was evaluated on 10 randomly selected fruits free of blemishes using a fruit texture penetrometer (Lake City Technical Products, Model FT 327; Kelowna, B.C.), equipped with a $7.9-\mathrm{mm}$ probe. Two measurements at $90^{\circ}$ from the suture were made on the fruit after an $\sim 2-\mathrm{mm}$ tangential section of skin was peeled from the equator of the fruit. Soluble solids concentration was measured using a digital refractometer (Abbe model 10450; American Optical Corp., Buffalo, N.Y.) from a composite sample of juice, expressed while measuring fruit firmness.

\section{'Harrow Diamond' 2003}

In 2003, the same 12 treatments were applied to single whole trees in a randomized complete block design with four replications on 5-year-old 'Harrow Diamond' peach trees grafted on 'Bailey' rootstock. Trees were spaced at $1.5 \mathrm{~m}$ within rows and $5.0 \mathrm{~m}$ between rows (1333 trees/ha), and trained to a fusetto (spindle) orchard system. To prevent spray drift, one guard row was left between experimental rows, and one guard tree was left between experimental units. Trees were managed according to standard practices for Ontario (Anonymous, 2004). The "early" sprays were applied on 21 May at $80 \%$ full bloom, and the "late" treatments were applied on 23 May on a different group of trees at $100 \%$ full bloom. A hand spray gun (Green Garde JD9-C; Rittenhouse, Ontario), connected to custom-fabricated sprayer (Rittenhouse) was used to apply sprays at a rate of $6600 \mathrm{~L} \cdot \mathrm{ha}^{-1}$.

Four representative scaffold limbs per tree, $\sim 2.0$ to $2.5 \mathrm{~cm}$ in diameter at the base and situated between 1.0 to $2.0 \mathrm{~m}$ above the ground, were tagged at bloom and the number of flower buds counted, and the length of all 1 -year-old shoots on these branches was measured. To avoid structural damage to trees and to compare these data with commercial practices, all treatments except the untreated control treatments were hand thinned on 14 July (52 day after bloom) to a commercial level of 15 to $20 \mathrm{~cm}$ distance between fruit. Most of the chemically treated trees needed only light thinning. The total weight and number of thinned fruit per tree were recorded, and the mean weight of thinned fruit was determined. Fruit were harvested on $18 \mathrm{Aug}$. and the weight and total number of fruit harvested per tree were recorded. Fruit size distribution was determined on a $5.5-\mathrm{kg}$ subsample of fruit per tree using the following commercial size categories: 51, 54, 57, 60, 64, and $67 \mathrm{~mm}$. Fruit firmness and soluble solids were measured on 20 randomly sampled fruit. Two measurements perpendicular to the suture were made using an electronic penetrometer (Fruit Texture Analyzer model GS-14; GUSS, South Africa), after a $\sim 2-\mathrm{mm}$ tangential section of skin was peeled from the equator of the fruit. Soluble solids was measured as in experiment 1. Leaf phytotoxicity was evaluated shortly after treatment imposition using a visual rating of severity from 0 (none) to 5 (severe).

Trunk circumference in both experiments was measured during the spring and autumn while the trees were dormant at $30 \mathrm{~cm}$ above the graft union.

Data were analyzed by PROC GLM using SAS practices (SAS Institute, Inc., Cary, N.C.), and mean separation was performed using Fisher's protected LSD. To evaluate the effect of thinners on mean fruit weight at harvest, analysis of covariance was performed. Crop load is reported to affect fruit maturity (Quinlan and Preston, 1968) and varied from tree to tree. Thus, when analyzing mean fruit weight, crop load was added as a covariate to the analysis. This is expressed as "crop load adjustment for fruit weight" (Marini et al., 2002). Analyses of orthogonal contrasts were performed to assess the effects of treatments by PROC GLM (Bowley, 1999). Data for thinners and data for timings were pooled to conduct the orthogonal comparisons.

\section{Results and Discussion}

In 2002, blossom thinners significantly reduced final fruit set per unit shoot length of 'Redhaven' peaches compared with untreated control (Table 1). The "early" $30 \mathrm{ml} \cdot \mathrm{L}^{-1}$ ATS treatment and both "late" $30 \mathrm{ml} \cdot \mathrm{L}^{-1}$ decyl alcohol and ATS applications reduced the final fruit set beyond the reduction observed from the hand-thinned treatment. The number of fruit per tree at harvest was significantly reduced for the entire blossomthinning treatments in comparison with the untreated control treatment, and furthermore was similar to that of the hand-thinned treatment for most treatments. Despite the fact that no significant difference was found between the fruit set for the untreated control treatment and the hand-thinned treatment, the number of fruit harvested per tree was higher for untreated control trees. Because a good correlation between fruit set and number of fruit harvested per tree was found, we concluded that the lack of statistical treatment significance in number of fruit harvested per tree is likely the result of inherently high treeto-tree variability within the orchard. The "late" $30 \mathrm{ml} \cdot \mathrm{L}^{-1}$ ATS treatment reduced the number of fruit per tree at harvest even greater than the hand-thinned treatment. Crop density, expressed as a number of fruit per unit trunk cross-sectional area (TCSA), was not significantly reduced in trees treated with blossom thinners. Although 'Redhaven' is known to heavily set fruit and is reportedly more difficult to thin chemically than other peach cultivars (Byers and Lyons, 1984a), a crop load reduction of $69 \%$ and $65 \%$ was observed for the "late" $30 \mathrm{ml} \cdot \mathrm{L}^{-1}$ ATS and $40 \mathrm{ml} \cdot \mathrm{L}^{-1}$ decyl alcohol treatments respectively compared with the unthinned control treatment. The mean fruit size from all blossom-thinned treatment trees was similar to that of the hand-thinned controls, with the exception of fruit from trees treated with "late" applications of $40 \mathrm{ml} \cdot \mathrm{L}^{-1}$ lime sulfur and "early" applications of $15 \mathrm{ml} \cdot \mathrm{L}^{-1}$ ATS, which were both smaller. Total yield per tree (Table 1) and fruit soluble solids (data not shown) were unaffected by chemical concentration or timing. Fruit firmness was significantly reduced in trees receiving "late" applications of $30 \mathrm{ml} \cdot \mathrm{L}^{-1}$ decyl alcohol in comparison with the untreated and handthinned control treatments. Also, mean fruit weight at each harvest was increased by the "late" chemical applications. Although TCSA was similar between treatments (data not shown), shoot growth was greater in trees treated with the "late" treatment of $15 \mathrm{ml} \cdot \mathrm{L}^{-1}$ ATS and $30 \mathrm{ml} \cdot \mathrm{L}^{-1}$ decyl alcohol. The number of shoots per limb increased in trees that received "late" applications of $30 \mathrm{ml} \cdot \mathrm{L}^{-1}$ ATS and "early" applications of $40 \mathrm{ml} \cdot \mathrm{L}^{-1}$ decyl alcohol. No leaf phytotoxicity was observed in 2002 after the treatments were applied.

In 2003, all chemical thinning products significantly reduced final fruit set in 'Harrow Diamond' in comparison with the untreated control treatment (Table 2). The thinning response was greatest for decyl alcohol, followed by ATS, and lime sulfur treatments. "Early" applications at $80 \%$ full bloom resulted in a greater reduction in the fruit density at fruit set, indicating there was a significant timing effect. All chemical products significantly reduced crop density at harvest; the greatest response was achieved from decyl alcohol, followed by ATS and lime sulfur. Although there were no significant differences in total yield between lime sulfur and control treatments, decyl alcohol and ATS treatments reduced yield per tree (data not shown). In comparison with the untreated control treatment, all treatments significantly reduced the number of fruit per tree at harvest, as well as yield efficiency. Blossom thinners significantly increased the percentage of fruit $\geq 67 \mathrm{~mm}$ in diameter. The effect of decyl alcohol treatments on fruit size was greatest, whereas the effect of lime sulfur was not significant at either timings. 


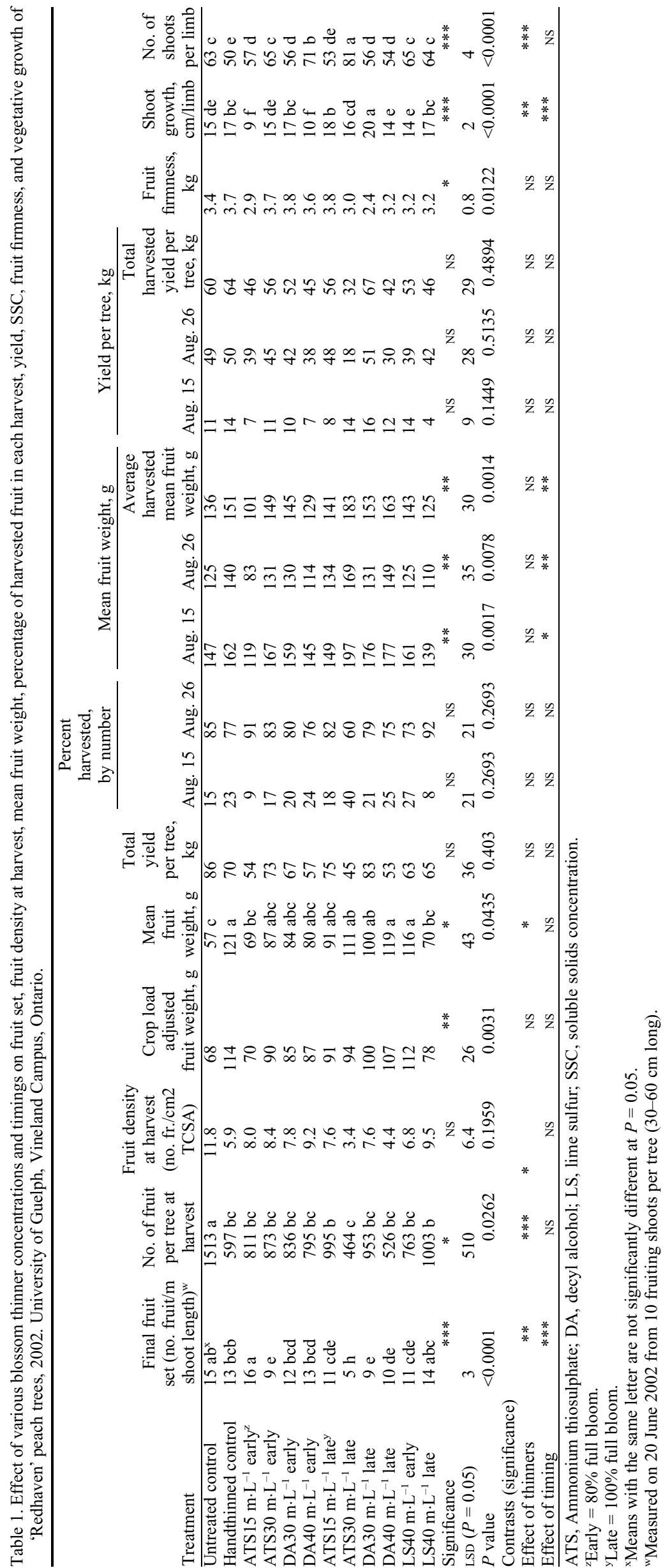

Soluble solids concentration did not differ significantly between the treatments, but tended to be higher for trees with reduced crop loads. Fruit from trees that received blossom thinning had decreased fruit firmness, particularly when applied early.

The requirement for follow-up hand thinning was significantly $(P<0.0001)$ less for trees that were blossom thinned compared with trees from hand-thinned control treatments (Fig. 1). This reduction varied from $30 \%$ to $90 \%$ of the number of fruit handthinned from the control trees, and was greatest for decyl alcohol and ATS treatments, followed by lime sulfur treatments. There was no treatment effect on the mean weight of thinned fruitlets. However, orthogonal contrasts indicated a significant $(P=$ $0.0247)$ increase in the fruit size of thinned fruitlets from trees received the lower rate of ATS. Mean fruit weight at harvest was significantly greater for all thinning treatments (Fig. 2) and was inversely proportional to the reduction in crop load.

In 2003, severe leaf phytotoxicity was observed on 'Harrow Diamond' trees within 1 week of applying the treatments. The phytotoxic response was greatest for ATS, especially at rates of $30 \mathrm{ml} \cdot \mathrm{L}^{-1}$ (Table 2). Similar phytotoxicity was reported after monocarbamide dihydrogen sulfate was applied to nectarines (Klein and Cohen, 1995), which resulted in the defruiting of the tree. Lime sulfur applications of $40 \mathrm{ml} \cdot \mathrm{L}^{-1}$ were not phytotoxic to leaves or fruit. Guak and colleauges (2004) observed that 4\% lime sulfur had less leaf burn in comparison with $1.6 \%$ ATS. Balkhoven-Baart and Wertheim (1997) indicated that spraying blossom thinners on wet leaves can cause severe leaf damage. In our experiments, chemical thinners were applied under dry weather conditions. In the current experiment on 'Harrow Diamond', significant leaf phytotoxicity was observed after chemical application using a hand spray gun, most likely a result of overspraying. This is consistent with the observations made by Byers and associates (2003) who reported that hand spray gun applications of $1170 \mathrm{~L} / \mathrm{ha}$ almost defruited trees, whereas air-blast sprayer applications at the same water volume resulted in the desired crop load. According to some (Dennis and Hull, 2003; Lilleland, 1965) some species such as Prunus, in which leaf development occurs after flower opening, are less affected by foliar damage incited by caustic blossom thinners in comparison with species such as apple, in which leaf development occurs after flowering. A compounding reason for explaining greater leaf phytotoxicity to 'Harrow Diamond' peach trees in our experiment is that in 2003, bloom occurred about 30 days later than average for the region. At the time of spraying, leaf size of 'Harrow Diamond' trees had already expanded to about $6 \mathrm{~cm}$ in length, providing sufficient area for the leaves to become exposed to the spray compound, whereas typically the blossom period for peaches coincides with little or no leaf development. 
Table 2. Effect of various blossom thinner concentrations and timings on fruit set, fruit density at harvest, yield efficiency, percentage of large-size fruit, SSC, fruit firmness, leaf phytotoxicity, and trunk growth of 'Harrow Diamond' beach trees on Bailey rootstock 2003. University of Guelph, Vineland Campus, Ontario.

\begin{tabular}{|c|c|c|c|c|c|c|c|c|c|c|c|}
\hline Treatment $^{\mathrm{w}}$ & $\begin{array}{c}\text { Fruit } \\
\text { density } \\
\text { at set fr./m } \\
\text { shoot } \\
\text { length }\end{array}$ & $\begin{array}{c}\text { Fruit } \\
\text { density } \\
\text { at harvest } \\
\text { fruit } / \mathrm{cm}^{2} \\
\text { TCSA }\end{array}$ & $\begin{array}{c}\text { Crop } \\
\text { density } \\
\text { adjusted } \\
\text { fruit } \\
\text { weight, g }\end{array}$ & $\begin{array}{l}\text { Total no. of } \\
\text { fruit/tree }\end{array}$ & $\begin{array}{c}\text { Yield } \\
\text { efficiency } \\
\mathrm{kg} / \mathrm{cm}^{2} \\
\text { TCSA }\end{array}$ & $\begin{array}{l}\text { Percent fruit } 51 \\
\mathrm{~mm} \text { in diameter }\end{array}$ & $\begin{array}{c}\text { Percent fruit } \\
67 \mathrm{~mm} \text { in } \\
\text { diameter }\end{array}$ & Brix \% & $\begin{array}{l}\text { Firmness, } \\
\text { kg }\end{array}$ & $\begin{array}{c}\text { Leaf } \\
\text { phytotoxicity, } \\
0-5\end{array}$ & $\begin{array}{l}\text { Trunk } \\
\text { growth, } \\
\mathrm{cm}^{2}\end{array}$ \\
\hline Untreated control & $4.8 \mathrm{a}^{\mathrm{x}}$ & $13.5 \mathrm{a}$ & 106 & $618 \mathrm{a}$ & $0.9 \mathrm{a}$ & $50 \mathrm{a}$ & $8 \mathrm{de}$ & 8.4 & $0.99 \mathrm{ab}$ & $0.0 \mathrm{e}$ & $6.6 \mathrm{def}$ \\
\hline Handthinned control & $3.7 \mathrm{ab}$ & $9.7 \mathrm{~b}$ & 103 & $451 \mathrm{ab}$ & $0.8 \mathrm{a}$ & $32 \mathrm{ab}$ & $3 \mathrm{e}$ & 9.4 & 0.81 bcde & $0.0 \mathrm{e}$ & $5.1 \mathrm{f}$ \\
\hline ATS15 m.L $\mathrm{L}^{-1}$ early $^{\mathrm{z}}$ & $1.0 \mathrm{ef}$ & $4.2 \mathrm{de}$ & 117 & $231 \mathrm{~cd}$ & $0.5 \mathrm{bc}$ & $5 \mathrm{c}$ & 39 abcd & 10.1 & $0.63 \mathrm{de}$ & $1.1 \mathrm{de}$ & $10.0 \mathrm{abcd}$ \\
\hline ATS30 $\mathrm{m} \cdot \mathrm{L}^{-1}$ early & $0.5 \mathrm{f}$ & $2.4 \mathrm{de}$ & 107 & $106 \mathrm{~cd}$ & $0.3 \mathrm{~cd}$ & $9 \mathrm{c}$ & $46 \mathrm{abc}$ & 10.3 & $0.84 \mathrm{bcd}$ & $4.5 \mathrm{a}$ & 7.9 cdef \\
\hline DA30 $\mathrm{m} \cdot \mathrm{L}^{-1}$ early & $0.3 \mathrm{f}$ & $1.2 \mathrm{e}$ & 132 & $57 \mathrm{~d}$ & $0.2 \mathrm{~d}$ & $3 \mathrm{c}$ & $58 \mathrm{ab}$ & 11.0 & $0.89 \mathrm{bc}$ & $1.1 \mathrm{de}$ & $11.3 \mathrm{abc}$ \\
\hline DA40 $\mathrm{m} \cdot \mathrm{L}^{-1}$ early & $0.1 \mathrm{f}$ & $0.9 \mathrm{e}$ & 116 & $49 \mathrm{~d}$ & $0.1 \mathrm{~d}$ & $0 \mathrm{c}$ & $56 \mathrm{ab}$ & 9.9 & $0.63 \mathrm{e}$ & $3.1 \mathrm{ab}$ & $11.7 \mathrm{ab}$ \\
\hline ATS15 m.L $\mathrm{L}^{-1}$ late $^{\mathrm{y}}$ & $2.4 \mathrm{~cd}$ & $3.3 \mathrm{de}$ & 132 & $162 \mathrm{~cd}$ & $0.5 \mathrm{~b}$ & $3 \mathrm{c}$ & $52 \mathrm{ab}$ & 9.1 & 0.82 bcde & $1.0 \mathrm{de}$ & 8.0 bcdef \\
\hline ATS30 $\mathrm{m} \cdot \mathrm{L}^{-1}$ late & $1.3 \mathrm{def}$ & $2.5 \mathrm{de}$ & 113 & $114 \mathrm{~cd}$ & $0.3 \mathrm{~cd}$ & $2 \mathrm{c}$ & $48 \mathrm{abc}$ & 9.9 & 0.81 bcde & $2.9 \mathrm{bc}$ & $10.1 \mathrm{abcd}$ \\
\hline DA30 $\mathrm{m} \cdot \mathrm{L}^{-1}$ late & $1.0 \mathrm{ef}$ & $2.2 \mathrm{de}$ & 124 & $116 \mathrm{~cd}$ & $0.3 \mathrm{~cd}$ & $2 \mathrm{c}$ & $68 \mathrm{a}$ & 10.6 & 0.76 cde & 1.4 cde & $12.0 \mathrm{a}$ \\
\hline $\mathrm{DA} 40 \mathrm{~m} \cdot \mathrm{L}^{-1}$ late & 1.9 cde & $1.7 \mathrm{de}$ & 107 & $86 \mathrm{~cd}$ & $0.2 \mathrm{~d}$ & $3 \mathrm{c}$ & 33 bcde & 8.9 & $1.16 \mathrm{a}$ & $1.9 \mathrm{bcd}$ & 9.1 abcde \\
\hline $\mathrm{LS} 40 \mathrm{~m} \cdot \mathrm{L}^{-1}$ early & $3.1 \mathrm{bc}$ & $9.0 \mathrm{bc}$ & 106 & $428 \mathrm{ab}$ & $0.8 \mathrm{a}$ & $20 \mathrm{bc}$ & $10 \mathrm{de}$ & 9.5 & $0.64 \mathrm{de}$ & $0.1 \mathrm{e}^{4}$ & 5.9 ef \\
\hline $\mathrm{LS} 40 \mathrm{~m} \cdot \mathrm{L}^{-1}$ late & $2.4 \mathrm{~cd}$ & $5.3 \mathrm{~cd}$ & 114 & $267 \mathrm{bc}$ & $0.5 \mathrm{~b}$ & $11 \mathrm{bc}$ & 19 cde & 9.2 & $1.00 \mathrm{ab}$ & $0.5 \mathrm{de}$ & 9.4 abcde \\
\hline Significance & $* * *$ & $* * *$ & * & $* * *$ & $* * *$ & $* * *$ & $* * *$ & NS & $* * *$ & $* * *$ & $* *$ \\
\hline $\operatorname{LCD}(P=0.05)$ & 1.300 & 3.8 & 15 & 191 & 0.2 & 21.6 & 32 & 3.2 & 0.20 & 1.6 & 3.8 \\
\hline$P$ value & $<0.0001$ & $<0.0001$ & 0.0320 & $<0.0001$ & $<0.0001$ & $<0.0002$ & 0.0008 & 0.9182 & $<0.0001$ & $<0.0001$ & 0.0078 \\
\hline \multicolumn{12}{|c|}{ Contrasts (significance) } \\
\hline Effect of thinners & $* * *$ & $* * *$ & NS & $* * *$ & $* * *$ & $* * *$ & $* *$ & NS & $*$ & $* *$ & $* *$ \\
\hline Effect of timing & $* *$ & NS & NS & NS & NS & NS & NS & NS & $* * *$ & NS & NS \\
\hline
\end{tabular}

${ }^{\mathrm{z}}$ Early $=80 \%$ full bloom.

${ }^{\mathrm{y}}$ Late $=100 \%$ full bloom

${ }^{x}$ Means with the same letter are not significantly different at $P=0.05$.

${ }^{\mathrm{w}} \mathrm{ATS}$, ammonium thiosulphate; DA, decyl alocohol; LS, lime sulfur; SSC, soluble solids concentration.

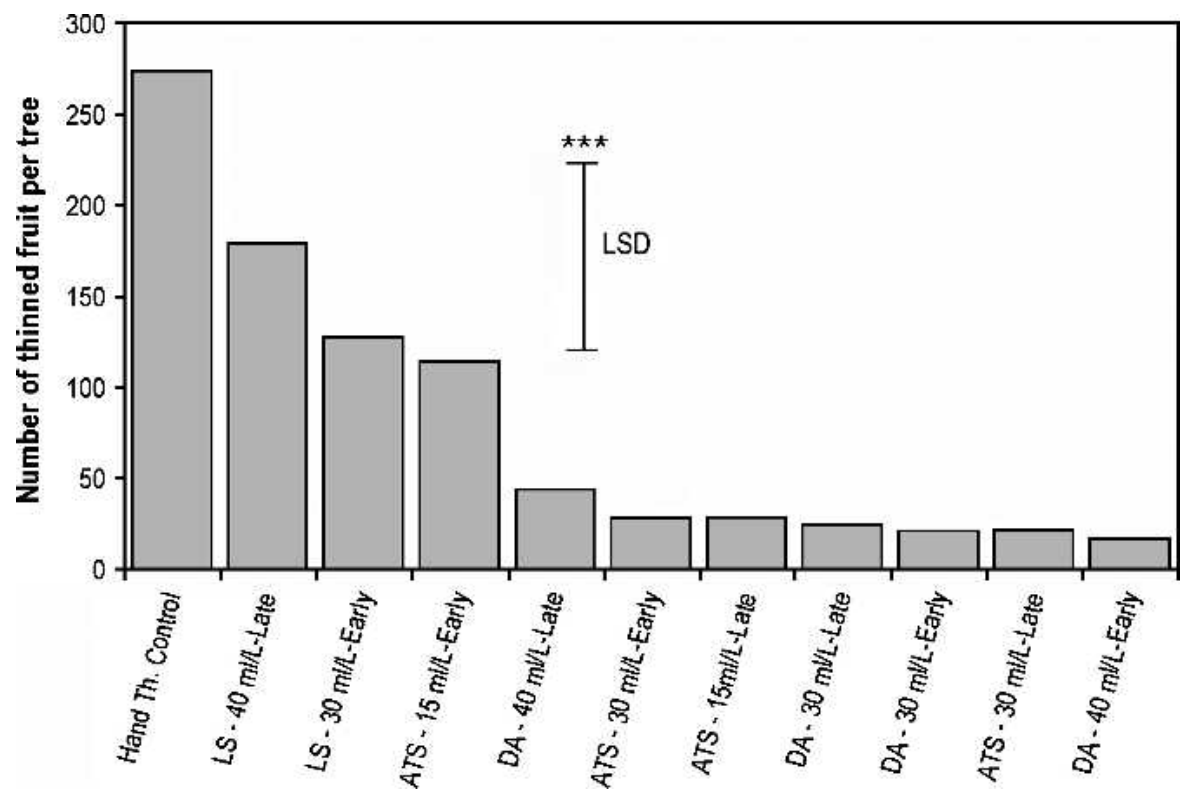

Fig. 1. Effect of various blossom thinner concentrations and timings on the requirement for hand thinning of 'Harrow Diamond' peaches in 2003.

It therefore appears that the phenological state of the leaves and flowers can greatly influence their response to chemical blossom thinners, and that this should be considered an important factor at the time of application.

Vegetative growth of 'Harrow Diamond', expressed as a change in TCSA, was significantly increased by decyl alcohol treatments in 2003. This is consistent with the results of Byers (1989), who reported that bloomthinned peach trees were found to have greater tree vigor than hand-thinned trees.
Hand thinning is one of the most important and expensive cultural practices associated with peach production (Marini, 2002; Southwick et al., 1995, 1998). Chemical products used as blossom thinners in this study reduced final fruit set and consequently the need for hand thinning in 'Redhaven' and 'Harrow Diamond' peach cultivars when applied at 80 to $100 \%$ full bloom. Reduction in hand thinning of between $50 \%$ to $80 \%$ was reported by Greene and coworkers (2001) when 'Redhaven' and 'Garnet Beauty' peach trees were sprayed with ATS at bloom. In the current study, the reduction in 'Redhaven' fruit set was between $20 \%$ and $80 \%$, and for 'Harrow Diamond' between $40 \%$ and $100 \%$. The reduction in hand thinning after blossom thinning can provide significant cost savings.

The observation that the thinning response was influenced by the time of application suggests that the interference blossom thinners have on flower pollination and fertilization is very important. Chemical applications at earlier stages of bloom may prevent a greater percentage of flowers to set fruit by preventing pollination or pollen tube growth. Environmental factors at and shortly after the time of application are also likely to influence the physiological response of the plant to the thinner. Also, the strong thinning response in 2003 may be a result of stress initiated by leaf and flower phytotoxicity.

Significant increases in fruit size were measured after chemical blossom thinning in both years of this study. The greatest effect was observed from decyl alcohol-treated trees - fruit weight from these trees was up to two times greater at harvest than the fruit size from untreated control trees. Decyl alcohol, ATS, and lime sulfur treatments significantly increased fruit size, not only when compared with untreated control trees, but also when contrasted against handthinned controls in 2003 (data not shown). Similar results have been reported elsewhere (Byers, 1989; Byers and Lyons, 1985; Byers et al., 1990; Chanana et al., 2002; Southwick et al., 1996). ATS treatments at a rate of 15 $\mathrm{ml} \cdot \mathrm{L}^{-1}$ increased fruit size at the endocarp hardening stage in 2003.

There are two major factors in how chemical thinners might influence fruit weight: One is their ability to reduce crop 


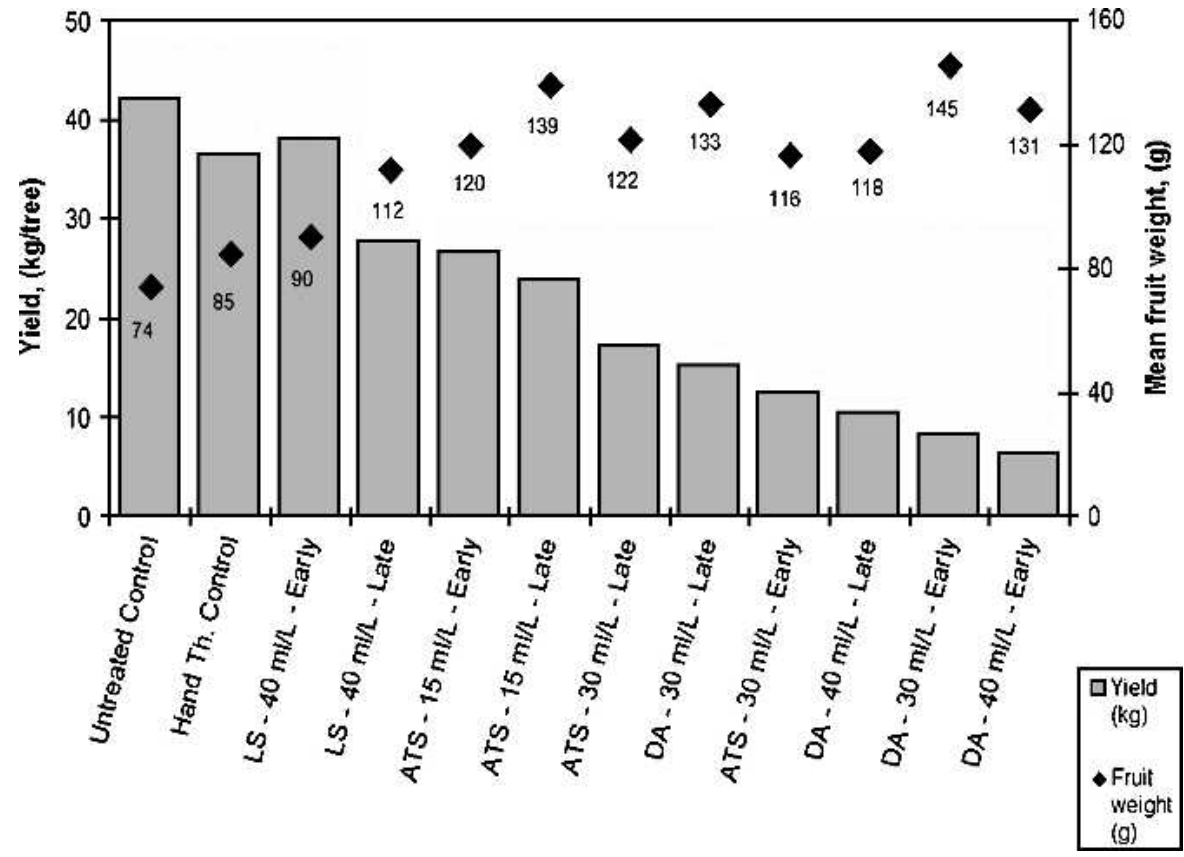

Fig. 2. Effect of various blossom thinner concentrations and timings on yield and mean fruit weight of 'Harrow Diamond' peaches in 2003.

load, which indirectly affects fruit weight by reducing interfruit competition. The other factor is their direct effect on fruit growth (Greene et al., 1990; Wismer et al., 1995). In the latter case, when chemical thinning is done during the fruit cell division period (2-4 weeks after anthesis), it may increase cell division and thereby enhance fruit size. Analysis of fruit size, using crop density as a covariate, indicated that the enhancement in fruit size at harvest was principally the result of reduced competition among fruits evident by lower crop density, rather than the result of a direct effect of thinners on cell division or other physiological processes early during the season (Tables 1 and 2). When the fruit size was plotted against crop density at harvest (number of fruit per square centimeter TCSA), no significant differences between blossom thinners and hand-thinned controls were observed in 2002 (data not shown). The increased percentage of harvested 'Redhaven' fruit on the first harvest date, incited by the "late" $30 \mathrm{~mL} \cdot \mathrm{L}^{-1}$ ATS treatment, is most likely a result of the crop load reduction, rather than a direct effect of the chemical on fruit maturity. In 2003, only the lower rate of decyl alcohol, as well as "late" application of $15 \mathrm{~mL} \cdot \mathrm{L}^{-1}$ ATS, effectively increased fruit size of 'Harrow Diamond' peaches, beyond the crop load effect alone.

The reason why the majority of blossom thinners failed to increase fruit size above the hand-thinned controls is not clear. We hypothesized that the treatments that effectively thinned the blossoms would have benefited from increased fruit size in comparison with hand-thinned treatments as a consequence of the early reallocation of photosynthates into fruit that would persist until harvest. It is evident from the data that final fruit size for the chemical thinners was closely associated with final crop density, and that fruit that was thinned early did not achieve an incremental increase in size. Only those treatments that caused limited or no phytotoxicity realized greater fruit size above the crop density effect alone. The severe leaf phytotoxicity incited by higher rates of ATS and decyl alcohol treatments in 2003 likely resulted in leaf loss during the critical period for fruit development early in the growing season. The loss in photosynthetic capacity as a result of leaf injury may have led to a deficit in carbon supply to developing fruits. Consequently, the enhancement in fruit weight beyond the effect contributed by a reduced crop density may have been negated. Other authors also reported that ATS can be quite effective in reducing fruit set and final crop load, although it was far less effective than benzyl adenine for increasing fruit size (Costa et al., 2004).

Economic yield can, in some instances, be reduced by chemical thinning even when fruit size is increased. Overthinning was apparent in 'Harrow Diamond' in 2003, because fruit size increases from blossom thinning did not compensate for the reduction in yield. The "late" $30 \mathrm{~mL} \cdot \mathrm{L}^{-1}$ decyl alcohol treatment on 'Redhaven' resulted in larger fruit size with no yield reduction in 2002 , demonstrating that decyl alcohol is potentially more effective for better net returns.

Treatment effects on other fruit quality characteristics such as soluble solids and fruit firmness suggested a slight advancement in crop maturity. Although this response is likely an indirect effect of blossom thinners on the reduced crop density and increased fruit size, nevertheless the result would pro- vide producers of early maturing fresh market cultivars, in particular, the advantage of marketing their product earlier in the season. In regions where the risk of spring frost is substantial, a two-stage strategy of partial blossom thinning with decyl alcohol or ATS during the first stage combined with followup hand thinning at the time of natural fruit abscission during the second stage is a more conservative and realistic approach in realizing the benefits from early chemical thinning.

Furthermore, the efficacy of chemical thinners was likely influenced by the method of spraying (Byers et al., 2003). Hand spray gun applications made to 'Harrow Diamond' in 2003 seem to deliver higher chemical rate and overthinned the trees, whereas air-blast sprays applied in 2002 at lower rates had no unfavorable effect on 'Redhaven' peaches.

Results from the current study demonstrate that ATS, decyl alcohol, and lime sulfur can be effective peach thinners. However, more research is required to determine ideal concentrations and water volumes to use for different cultivars at different stages of bloom development. Also, research on the use of these blossom thinners on other Prunus species is warranted.

\section{Literature Cited}

Anonymous. 2004. Fruit production recommendations 2004-2005. Publication 360. Ontario Ministry of Agriculture, Food and Rural Affairs, Toronto, Ontario.

Balkoven-Baart, J.M.T. and S.J. Wertheim. 1997. Thinning response of 'Elstar' apple to the flower thinner ammonium thiosulphate (ATS). Acta Hort. 463:481-486.

Bowley, S.R. 1999. A hitchhiker's guide to statistics in plant biology. Plants et al., Inc. Guelph, Ontario.

Byers, R.E. 1989. Response of peach trees to bloom thinning. Acta Hort. 254:125-132.

Byers, R.E. 1999. Effect of bloom-thinning chemicals on peach fruit set. J. Tree Fruit Prod. 2:5978.

Byers, R.E., D.H. Carbaugh, and C.N. Presley. 1990. The influence of bloom thinning and $\mathrm{GA}_{3}$ sprays on flower bud numbers and distribution in peach trees. J. Hort. Sci. 65:143-150.

Byers, R.E., G. Costa, and G. Vizzotto. 2003. Flower and fruit thinning of peach and other Prunus. Hort. Rev. (Amer. Soc. Hort. Sci.) 28:351-392.

Byers, R.E. and C.G. Lyons, Jr. 1984a. Flower thinning of peach with desiccating chemicals. HortScience 19:545-546.

Byers, R.E. and C.G. Lyons, Jr. 1984b. Peach fruit abscission by shading and photosynthetic inhibition. HortScience 19:649-651.

Byers, R.E. and C.G. Lyons, Jr. 1985. Peach flower thinning and possible sites of action of desiccating chemicals. J. Amer. Soc. Hort. Sci. 110:662-667.

Chanana, Y.R., G.S. Kaundal, J.S. Kanwar, N.K Arora, and R.S. Saini. 2002. Effect of chemical and hand thinning on maturity, yield and fruit quality of peaches (Prunus persica (L.) Batsch.). Acta Hort. 592:309-313.

Costa, G., J. Bonany, J. Carbo, M. Casals, M Stopar, G. Lafer, A. Dorigoni, G. Vizzotto, and C. Bomben. 2004. Multilocation analysis of ATS and BA thinning efficacy on 'Golden Delicious'. Acta Hort. 636:303-310. 
Dennis, F.G., Jr., and J. Hull, Jr. 2003. Deciduous tree fruit. HortScience 38:901-910.

Fallahi, E. 1997. Applications of endothalic acid, pelargonic acid, and hydrogen cyanamide for blossom thinning in apple and peach. Horttechnology 7:395-399.

Fallahi, E., B. Fallahi, J.R. McFerson, R.E. Byers, R.C. Ebel, R.T. Boozer, J. Pitts, and B.S. Wilkins. In press. The influence of TergitolTMN-6 surfactant is an effective blossom thinner for stone fruits.

Fallahi, E., C.R. Rom, and B. Fallahi. 2003. Influence of organic blossom thinners on fruit set and quality in apples, peaches, and plum. HortScience 38:690.

Greene, D.W., W.R. Autio, and P. Miller. 1990. Thinning activity of benzyladenine on several apple cultivars. J. Amer. Soc. Hort. Sci. 115:394-400.

Greene, D.W., K.I. Hauschild, and J. Krupa. 2001. Effect of blossom thinners on fruit set and fruit size of peaches. Horttechnology 11:179-183.

Guak, S., M. Beulah, and N.E. Looney. 2004. Thinning of 'Fuji' and 'Gala' apple with lime sulphur and other chemicals. Acta Hort. 636:339-346.

Havis, A.L. 1962. Effects of time of fruit thinning of 'Redhaven' peach. Proc. Amer. Soc. Hort. Sci. 80:172-176.

Klein, J.D. and S. Cohen. 1995. High concentration of monocarbamide dihydrogensulphate are needed to thin nectarine blooms in Israel. HortScience 30:628.

Lilleland, O. 1965. Growth and thinning of peach fruit. Proc. Peach Congr. Verona 20(24):1-10.

Marini, R.P. 2002. Heading fruiting shoots before bloom is equally effective as blossom removal peach crop load management. HortScience 37:642-646.

Marini, R.P. 2003. Peach fruit weight, yield, and crop value are affected by number of fruiting shoots per tree. HortScience 38:512-514.

Marini, R.P., J.A. Barden, J.A. Cline, R.L. Perry, and T. Robinson. 2002. Effect of apple rootstocks on average 'Gala' fruit weight at four locations after adjusting for crop load. J. Amer. Soc. Hort. Sci. 127:749-753.

Meland, M. 1997. Thinning apples and pears in a Nordic climate. The effect of NAA, Ethephon and lime sulphur on fruit set, yield and return bloom of three apple cultivars. Acta Hort. 463:517-525.

Noordijk, H. and J. Schupp. 2003. Organic postbloom apple thinning with fish oil and lime sulfur. HortScience 38:690.

Quinlan, J.D. and A.D. Preston. 1968. Effect of thinning blossom and fruitlets on growth and cropping of 'Sunset' apple. J. Hort. Sci. 43:373381.

SAS Institute Inc. 1998. SAS/STAT guide for personal computers. V. 6.03. SAS Inst. Inc., Cary, N.C.

Slingerland, K. and J. Molenhuis (eds.). 2003. Establishment and production costs for tender fruit in Ontario: 2002 economic report. Publication 817. Ontario Ministry of Agriculture and Food. K. Slingerland and Queen's Printer for Ontario, Toronto, Canada.

Southwick, S.M. and R. Fritts, Jr. 1995. Commercial chemical thinning of stone fruit in California by gibberellins to reduce flowering. Acta Hortic. 394:135-147.

Southwick, S.M., K.G. Weis, and J.T. Yeager. 1995. Controlling cropping in 'Loadel' cling peach using gibberellin: effects on flower density, fruit distribution, fruit firmness, fruit thinning, and yield. J. Amer. Soc. Hort. Sc. 120:1087-1095.

Southwick, S.M., K.G. Weis, and J.T. Yeager. 1996. Bloom thinning 'Loadel' cling peach with a surfactant. J. Amer. Soc. Hort. Sci. 121:334338.

Southwick, S.M., K.G. Weis, J.T. Yeager, J.K. Hasey, and M.E. Rupert. 1998. Bloom thinning of 'Loadel' cling peach with a surfactant: Effects of concentration, carrier volume, and differential applications within the canopy. Horttechnology 8:55-58.

Unrath, C.R. 1974. The commercial implications of gibberellin $\mathrm{A}_{4} \mathrm{~A}_{7}$ plus benzyladenine for improving shape and yield of 'Delicious' apples. J. Amer. Soc. Hort. Sci. 99:381384.

Warner, G. 2002. Lime sulfur could be a thinning option. Good Fruit Grower. 15:10.

Webster, A.D. and L. Andrews. 1986. Flower and fruit thinning of 'Victoria' plum (Prunus domestica L.) with paclobutrazol. Acta Hort. 179:703-704.

Westwood, M.N. 1993. Chemical thinning, p. 267269. In: M.N. Westwood, ed., Temperate zone pomology. 3rd ed. Timber Press, Inc., Portland Ore.

Wismer, P.T., J.T.A. Proctor, and D.C. Elfving. 1995. Benzyladenine affects cell division and cell size during apple fruit thinning. J. Amer. Soc. Hort. Sci. 120:802-807. 